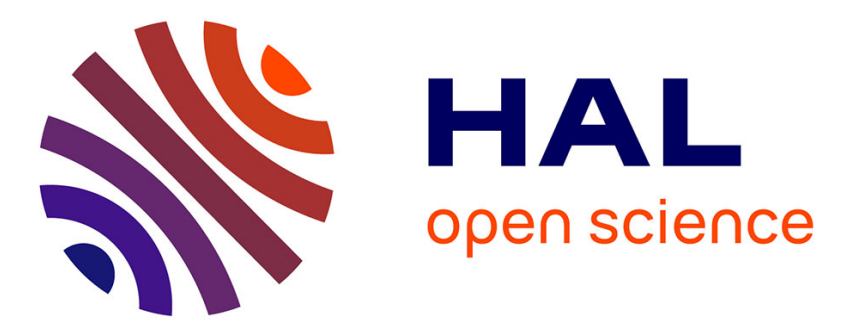

\title{
Experimental and theoretical characterization of microbial bioanodes formed in pulp and paper mill effluent in electrochemically controlled conditions
}

Stephanie F. Ketep, Eric Fourest, Alain Bergel

\section{- To cite this version:}

Stephanie F. Ketep, Eric Fourest, Alain Bergel. Experimental and theoretical characterization of microbial bioanodes formed in pulp and paper mill effluent in electrochemically controlled conditions. Bioresource Technology, 2013, vol. 149, pp. 117-125. 10.1016/j.biortech.2013.09.025 . hal-00877725

\author{
HAL Id: hal-00877725 \\ https://hal.science/hal-00877725
}

Submitted on 29 Oct 2013

HAL is a multi-disciplinary open access archive for the deposit and dissemination of scientific research documents, whether they are published or not. The documents may come from teaching and research institutions in France or abroad, or from public or private research centers.
L'archive ouverte pluridisciplinaire HAL, est destinée au dépôt et à la diffusion de documents scientifiques de niveau recherche, publiés ou non, émanant des établissements d'enseignement et de recherche français ou étrangers, des laboratoires publics ou privés. 


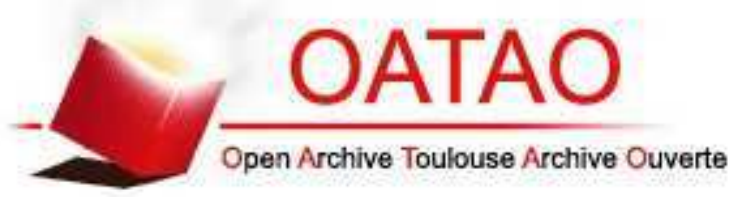

\section{Open Archive TOULOUSE Archive Ouverte (OATAO)}

OATAO is an open access repository that collects the work of Toulouse researchers and makes it freely available over the web where possible.

This is an author-deposited version published in : http://oatao.univ-toulouse.fr/ Eprints ID : 9931

To link to this article : doi:10.1016/j.biortech.2013.09.025

URL : http://dx.doi.org/10.1016/j.biortech.2013.09.025

To cite this version : Ketep, Stephanie F. and Fourest, Eric and Bergel, Alain Experimental and theoretical characterization of microbial bioanodes formed in pulp and paper mill effluent in electrochemically controlled conditions. (2013) Bioresource Technology, vol. 149 . pp. 117-125. ISSN 0960-8524

Any correspondance concerning this service should be sent to the repository administrator: staff-oatao@ listes-diff.inp-toulouse.fr 


\title{
Experimental and theoretical characterization of microbial bioanodes formed in pulp and paper mill effluent in electrochemically controlled conditions
}

\author{
Stephanie F. Ketep ${ }^{\mathrm{a}, \mathrm{b}}$, Eric Fourest ${ }^{\mathrm{a}}$, Alain Bergel $^{\mathrm{b}, *}$ \\ ${ }^{a}$ Centre Technique du Papier, BP 251, 38044 Grenoble Cedex 9, France \\ ${ }^{\mathrm{b}}$ Laboratoire de Génie Chimique (LGC), CNRS-Université de Toulouse (INPT), BP 84234, 31432 Toulouse, France
}

\section{H I G H L I G H T S}

- Microbial bioanodes were formed in raw pulp and paper mill effluent.

- In well-controlled conditions $4 \mathrm{~A} / \mathrm{m}^{2}$ were reached at $-0.3 \mathrm{~V} / \mathrm{ECS}$.

- A theoretical model determined the contribution of the bioanode to the COD removal.

- Electrochemical COD removal was proportional to HRT.

- Electrochemical COD removal obeyed a Michaelis-Menten law with the COD outlet.

\begin{abstract}
A B S T R A C T
Microbial bioanodes were formed in pulp and paper effluent on graphite plate electrodes under constant polarization at $-0.3 \mathrm{~V} / \mathrm{SCE}$, without any addition of nutriment or substrate. The bioanodes were characterized in 3-electrode set-ups, in continuous mode, with hydraulic retention times from 6 to $48 \mathrm{~h}$ and inlet COD from 500 to $5200 \mathrm{mg} / \mathrm{L}$. Current densities around $4 \mathrm{~A} / \mathrm{m}^{2}$ were obtained and voltammetry curves indicated that $6 \mathrm{~A} / \mathrm{m}^{2}$ could be reached at $+0.1 \mathrm{~V} / \mathrm{SCE}$. A theoretical model was designed, which allowed the effects of HRT and COD to be distinguished in the complex experimental data obtained with concomitant variations of the two parameters. COD removal due to the electrochemical process was proportional to the hydraulic retention time and obeyed a Michaelis-Menten law with respect to the COD of the outlet flow, with a Michaelis constant $K_{\mathrm{COD}}$ of $400 \mathrm{mg} / \mathrm{L}$. An inhibition effect occurred above inlet COD of around $3000 \mathrm{mg} / \mathrm{L}$.
\end{abstract}

Keywords:

Microbial anode

Pulp mill effluent

Microbial fuel cell

\section{Introduction}

The treatment of urban and industrial effluents is a major concern of modern society and is responsible for the consumption of large amounts of energy in developed countries. Various technologies are implemented, which generally require high electricity input, particularly for the aeration of the large tanks used in aerobic treatments (Youngho and Logan, 2010), and result in the production of substantial amounts of sludge (Li et al., 2007; Stephenson et al., 2012). In recent years, an increasing number of studies have aimed to adapt the emergent technology of microbial fuel cells (MFCs) to the treatment of effluents. MFCs would offer the great advantage of abating organic matter in anaerobic conditions, thus saving the cost of aeration. In addition, they could transform a part of the chemical energy contained in the organic matter directly into electricity (Logan and Rabaey, 2012).

\footnotetext{
* Corresponding author. Tel.: +33 534323673.

E-mail address: alain.bergel@ensiacet.fr (A. Bergel).
}

Paper-making is a water-intensive industrial sector that requires high volumes of water and produces high volumes of concentrated effluents. Nevertheless, few MFC studies have addressed paper mill effluents so far and they have shown only very modest performance in current and power generation (see Table 1 in Supplementary data). Abatements of the effluents' chemical oxygen demand (COD) generally seem satisfactory, but the low values of Coulombic efficiencies (CE) indicate that the electrochemical process makes only a minor contribution to COD removal. Under continuous flow in an air cathode MFC, Liu et al. obtained CE of $12 \%$ with the effluent from a treatment plant (Liu et al., 2004); Cheng et al. found maximal CE of $27 \%$ with domestic wastewater (Cheng et al., 2006). Several other studies using raw effluents have exhibited very low Coulombic efficiencies, between 1\% and 5\% (Youngho and Logan, 2010; Wen et al., 2010; Lee et al., 2010; Kassongo and Togo, 2011; Lefebvre et al., 2013). It is thus widely agreed that a substantial fraction of organic matter is oxidized in alternative ways such as aerobic respiration or anaerobic pathways due to the presence of dissolved electron acceptors (nitrate, sulphate) 
(Min et al., 2005; You et al., 2006; Lu et al., 2009). In parallel, fermentation processes cannot be ruled out and biomass growth has also been suggested to account for part of COD removal (Min and Logan, 2004; Liu et al., 2004). The formation of microbial bioanodes in raw effluents is consequently hard to investigate because of the large part of COD removal that is not related to electrochemical reactions.

The purpose of the present study was to identify the electrochemical performance that microbial bioanodes formed in pulp and paper effluents could reach, using well controlled electrochemical conditions. Most studies using raw industrial effluents have been carried out in whole MFC devices so far. MFCs are quite complex systems in which various processes occur and can interact (anode and cathode kinetics, diffusion and migration in different media including membrane, etc.) and multiply the number of possible causes of rate limitation. In contrast, in the present study, an electroanalysis cell including a 3-electrode set-up was used to rigorously control the potential of the microbial bioanode and to avoid any rate limitation not related to the bioanode kinetics. In particular, the high internal resistance of MFC due to the low conductivity of effluents was overcome by locating the reference electrode very close to the bioanode surface. A small electrode surface area $\left(10 \mathrm{~cm}^{2}\right)$ was used in a large volume of effluent $(0.5 \mathrm{~L})$ to favour a uniform current distribution and to maintain stable substrate concentration in the reactor. Furthermore, smooth graphite plate electrodes were used to avoid morphological enhancing effects. This cell design was established according to conventional electroanalytical rules in order to characterize the intrinsic bioanode behaviour in electrochemically rigorous conditions. Obviously, the same design would not be suitable for an industrial reactor, in which the electrode surface area must be as large as possible, the electrode morphology must favour local current heterogeneities and the use of a reference electrode cannot be contemplated. Similarly, nitrogen was sparged continuously in the electroanalysis cell to avoid aerobic side-oxidations, while it would not be useful at the industrial scale.

The electroanalysis cells were fed with effluents at different COD concentrations supplied in continuous mode with different hydraulic retention times (HRT). To remain as close as possible to industrial conditions, the effluent was used as collected from the treatment unit, without any input of nutrients or addition of substrate. This was an original approach with respect to current literature. Less than $30 \%$ of the studies dealing with MFCs have operated in continuous mode and most were conducted with pure substrates (Zhang et al., 2013).

A theoretical approach was also developed to extract conclusions from experimental data that varied in a complex manner due to the evolution of the raw effluent during long-lasting experiments. As far as we know, this study was the first attempt to use well-controlled electrochemical conditions when characterizing bioanodes operating in continuous mode in a raw effluent.

\section{Experimental section}

\subsection{Effluent}

Effluent from a recycled paper producing mill was collected at the outlet of the anaerobic effluent treatment step with COD ranging from 1400 to $1650 \mathrm{mg} / \mathrm{L}, \mathrm{pH}$ of $7.15 \pm 0.15$ and conductivity of $3.3 \mathrm{~ms} / \mathrm{cm}$. It was stored at $4{ }^{\circ} \mathrm{C}$ until used. This effluent was used as sole inoculum and substrate source without addition of any nutrients or trace minerals. Lower COD values were obtained by diluting the raw effluent with fresh water. Higher COD values were reached by mixing effluents collected at the outlet and the inlet of the anaerobic process (inlet COD up to $5200 \mathrm{mg} / \mathrm{L}$ ).

\subsection{Bioanode formation and continuous reactor operation}

Working electrodes were flat $2 \mathrm{~cm} \times 5 \mathrm{~cm} \times 0.5 \mathrm{~cm}$ graphite plates (Goodfellow) electrically connected via screwed titanium wires (Alfa Aesar). Current densities were calculated with respect to the $10 \mathrm{~cm}^{2}$ projected surface area. Before use, the graphite electrodes were cleaned by $1 \mathrm{~h}$ in $1.0 \mathrm{M} \mathrm{HCl}, 20$ min rinsing with distilled water, $1 \mathrm{~h}$ in $1.0 \mathrm{M} \mathrm{NaOH}$ and final thorough rinsing with distilled water. Auxiliary electrodes were $90 \%$ Platinum-10\% Iridium grids (Heraeus). Potentials were controlled versus a saturated calomel electrode (SCE; potential +0.24 V/SHE; Radiometer, Copenhagen) using a multi-channel potentiostat (Bio-Logic SA). All experiments were achieved under constant applied potential (chronoamperometry, CA) at $-0.3 \mathrm{~V} / \mathrm{SCE}$. The applied potential was periodically suspended to record cyclic voltammetry (CV) curves at $1 \mathrm{mV} / \mathrm{s}$. The reactors were maintained at $25^{\circ} \mathrm{C}$ in a temperature-controlled room and were continuously sparged with $\mathrm{N}_{2}$ to maintain anaerobic conditions. Replicates were systematically performed as discussed below.

The bioanodes were firstly formed for around 1 week in batch mode, i.e. with the reactor filled with $500 \mathrm{~mL}$ raw effluent in the absence of any flow. The reactors were then continuously fed with the raw effluent thanks to a peristaltic pump. The flow rate was varied from of 250 to $2000 \mathrm{~mL} /$ day by steps of around a week each, which gave hydraulic retention time (HRT) values from 48 to $6 \mathrm{~h}$, respectively. During the experiments, the tank, in which the effluent was stored, was kept at $4{ }^{\circ} \mathrm{C}$ under nitrogen.

Samples were collected daily from the influents (input) and effluents (output) of the reactors to measure their COD according to the ISO 15705 standard micro-method using Merck reagents and a WTW Photolab ${ }^{\circledR} 6000$ spectrophotometer.

\subsection{Calculations}

Only the definitions of the conventional parameters are recalled in this section. The modelling work is described in Section 3.2.1. Hydraulic retention time (HRT, s) is the ratio of the solution volume in the reactor $V_{\mathrm{S}}\left(0.5 \times 10^{-3} \mathrm{~m}^{3}\right)$ to the volumetric flow rate $\left(\dot{V}, \mathrm{~m}^{3} / \mathrm{s}\right)$ :

$\mathrm{HRT}=\frac{V_{S}}{\dot{V}}$

The total COD removal $\left(\triangle \mathrm{COD}, \mathrm{mg} / \mathrm{L}\right.$ or $\left.\mathrm{g} / \mathrm{m}^{3}\right)$ was defined as the difference between the input and output $C O D$ values:

$\triangle \mathrm{COD}=\mathrm{COD}_{\text {input }}-\mathrm{COD}_{\text {output }}$

and the total COD removal yield (\%) was:

$Y_{\mathrm{COD}}=\frac{\Delta \mathrm{COD}}{\mathrm{COD}_{\text {input }}} \cdot 100$

The average $Y_{\mathrm{COD}}$ values reported in the tables and figures were calculated from 5 to 7 daily measurements of $\mathrm{COD}_{\text {input }}$ and $\mathrm{COD}_{\text {output }}$. Experimental errors on COD abatements were calculated as follows:

$2 \times u_{\mathrm{DCO}}=2 \times\left[\frac{1}{\left.\mathrm{DCO}_{\text {input }}\right]}\right] \sqrt{\left.u_{\left(\mathrm{DCO}_{\text {input }}\right)}^{2}+u_{\left(\mathrm{DCO}_{\text {oupput }}\right)}^{2}+\frac{\left(\mathrm{DCO}_{\text {input }}-\mathrm{DCO}_{\text {output }}\right)^{2}}{\mathrm{DCO}_{\text {input }}^{2}} \cdot u_{\left(\mathrm{DCO}_{\text {output }}\right.}^{2}\right)}$,

where $u=30 \mathrm{mg} / \mathrm{L}$ is the experimental error on each COD measurement related to the measurement kit. In all cases, experimental errors on $Y_{\mathrm{COD}}$ were of 5-6\%. Coulombic efficiency (CE) was calculated as the charge passed through the circuit $(Q)$, calculated by integrating the current over a given period of time, to the charge that could be produced by complete oxidation of the effluent supplied during the same period $\left(Q_{\max }\right)$ :

$\mathrm{CE}=\frac{Q}{Q_{\max }}$ 
In continuous mode, assuming stable values of the concentration in the inlet and outlet flows, the theoretical charge is:

$Q_{\max }=n F \dot{V} \Delta t\left(\mathrm{COD}_{\text {input }}-\mathrm{COD}_{\text {output }}\right) / M_{\mathrm{O}_{2}}$

where $n=4$ is the number of electrons exchanged per mol of oxygen, $F=96485 \mathrm{C} / \mathrm{mol} e^{-}$is the Faraday constant, $\Delta t$ is the period of time considered (s), COD is the chemical oxygen demand in the input and output flows $\left(\mathrm{mg} / \mathrm{L} \mathrm{or} \mathrm{g} / \mathrm{m}^{3}\right), M_{\mathrm{O}_{2}}=32 \mathrm{~g} / \mathrm{mol}$ is the molar mass of oxygen, so that:

$\mathrm{CE}=\frac{32 F}{4} \frac{Q}{\Delta t \cdot \dot{V} \cdot \Delta \mathrm{COD}}$

\section{Experimental results and modelling}

\subsection{Effect of the hydraulic retention time (HRT)}

\subsubsection{Evolution of current density with time}

The reactor was kept in batch mode for 5 days to form the bioanode from the raw effluent without addition of any complement or substrate. It was then switched to the continuous mode, where it was fed with raw effluent at constant flow rate. The current increased as soon as the flow was started and presented a brief peak reaching $6.4 \mathrm{~A} / \mathrm{m}^{2}$, which was hard to explain (Fig. $1 \mathrm{~A}$ ). During the first period, an attempt was made to stabilize HRT around $48 \mathrm{~h}$ but it varied between 40 and $50 \mathrm{~h}$ because flow rate stability was technically difficult to ensure at the very low value of $250 \mathrm{~mL} /$ day. During this first phase at HRT around $48 \mathrm{~h}$, and except for the initial high current peak, the bioanode produced an average current density of $3.5 \pm 0.5 \mathrm{~A} / \mathrm{m}^{2}$. Then, decreasing HRT to 24,12 and $6 \mathrm{~h}$ by successive periods of 1 week each led to identical current densities of $4.5 \pm 0.5 \mathrm{~A} / \mathrm{m}^{2}$.

The performance of the microbial anode was also characterized over the whole range of potential by recording cyclic voltammetry $(1 \mathrm{mV} / \mathrm{s})$. It was verified that $\mathrm{CV}$ recorded at the beginning of the experiment with the clean electrode (day 0 ) did not give any current (data not shown), confirming that the oxidation currents observed in the subsequent CVs were related to the formation of an electroactive biofilm. Fig. 1B reports a typical CV obtained during reactor operation (day 18) and the CV recorded at the end of the

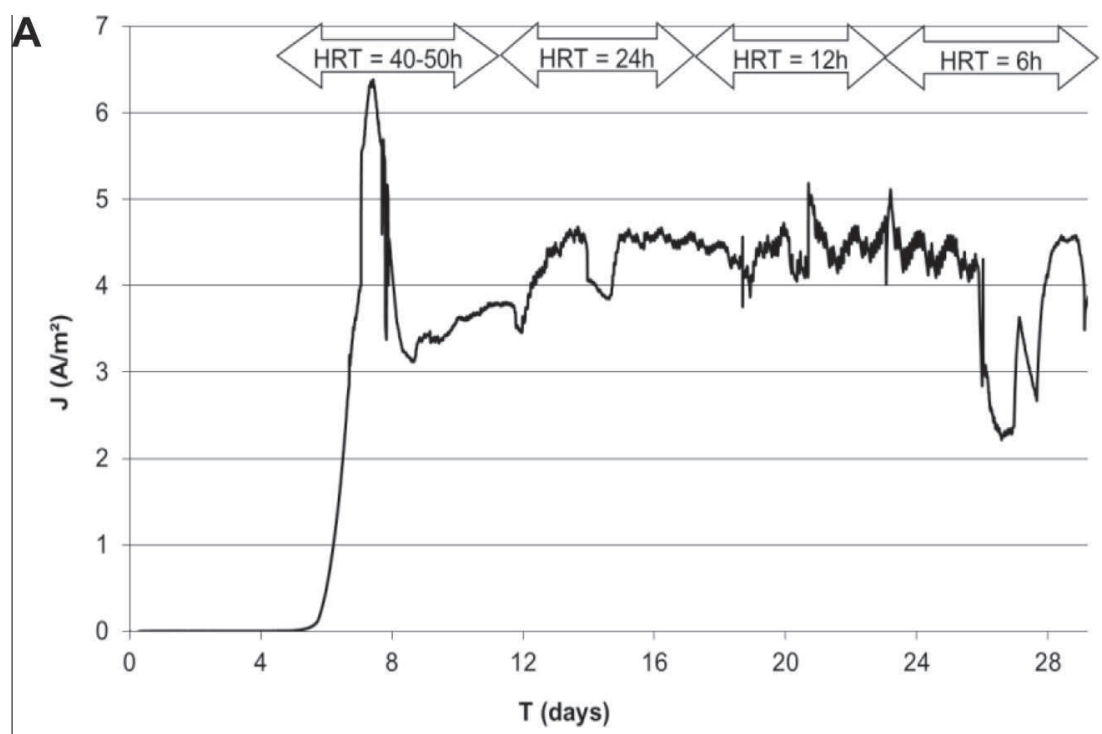

B $\cdots \cdots . . . \mathrm{C} \mathrm{V}$ at the beginning $(\mathrm{t}=0)--\mathrm{CV}$ at the maximum current $(\mathrm{t}=18)-\mathrm{CV}$ at the end $(\mathrm{t}=30)$

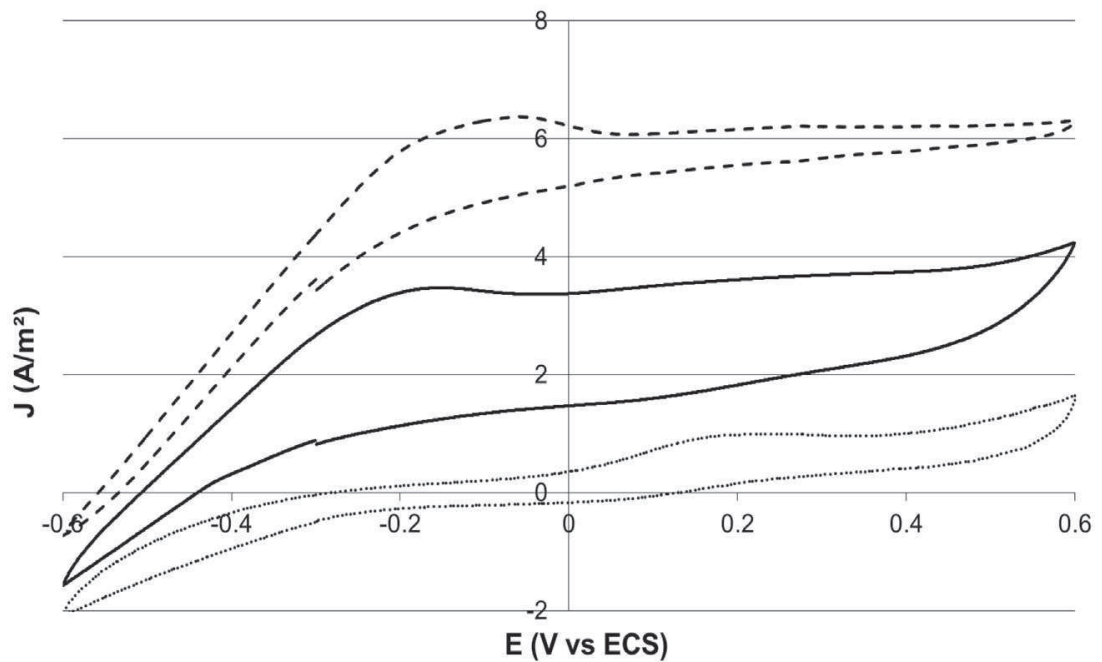

Fig. 1. Microbial bioanode formed and operated in continuous mode under constant polarization at $-0.3 \mathrm{~V} / \mathrm{SCE}$. (A) Current density as a function of time at different HRT values. The first 5 days corresponded to the bioanode formation in batch mode; (B) cyclic voltammetry ( $1 \mathrm{mV} / \mathrm{s}$ ) at day 18 and at the end of the experiment (day 29 ). 
experiment. The final CV showed greater hysteresis, indicating that the 29-day old bioanode produced larger capacitive currents. Over the course of the experiment, microbial cells produced exopolymeric substances resulting in a final compact biofilm (Supplementary data, Fig. 1), which accumulated ions and other compounds coming from the effluent. The interfacial capacity consequently increased with ageing as shown by the CV record. We have already observed this phenomenon during ageing of other microbial bioanodes formed in raw industrial effluent (data to be published).

For each $\mathrm{CV}$, the current density measured at $-0.3 \mathrm{~V} / \mathrm{SCE}$ was of the same order of magnitude as the current density obtained during chronoamperometry (forward scans: $4.3 \mathrm{~A} / \mathrm{m}^{2}$ at day 18 and $2.8 \mathrm{~A} / \mathrm{m}^{2}$ at day 29). The scan rate of $1 \mathrm{mV} / \mathrm{s}$ was consequently low enough to characterize the stationary behaviour of the electrodes. Maximum current densities of $6 \mathrm{~A} / \mathrm{m}^{2}$ obtained above $0.2 \mathrm{~V} / \mathrm{SCE}$. CV showed that the potential of $-0.3 \mathrm{~V} / \mathrm{SCE}$ that was chosen here did not ensure the highest possible current density. $5 \mathrm{~A} / \mathrm{m}^{2}$ could be reached at $-0.2 \mathrm{~V} / \mathrm{SCE}$ and close to $6 \mathrm{~A} / \mathrm{m}^{2}$ at $0.0 \mathrm{~V} / \mathrm{SCE}$. Nevertheless, when the objective is to design efficient microbial electrochemical systems, a bioanode must ensure the highest possible current density at the lowest possible potential. Here the applied potential of $-0.3 \mathrm{~V} / \mathrm{SCE}$ ensured currents of $75 \%$ of the maximum current and was low enough for the bioanode to be efficient in a microbial electrochemical system. The value of $-0.3 \mathrm{~V} / \mathrm{SCE}$ was consequently kept for the entire study because it represented a satisfactory compromise between the two opposing purposes: increasing current while decreasing the potential.

The experiment was replicated twice. One replicate produced identical stable current densities around $4.5 \pm 0.5 \mathrm{~A} / \mathrm{m}^{2}$, the other slightly lower values around $3 \pm 0.5 \mathrm{~A} / \mathrm{m}^{2}$ (Table 1 ). These current densities were considerably higher than the values reported in the literature so far for MFCs using raw effluents; for instance it was 3 times the highest current obtained with paper-making effluent $\left(1.6 \mathrm{~A} / \mathrm{m}^{2}\right.$ from Mathuriya and Sharma, 2009a, see details in Table 1 in Supplementary data). Moreover, these current densities were obtained with flat non-porous electrodes. The current density was consequently not enhanced by any porous or three-dimensional effect. As expected, the electrochemically well-controlled experimental conditions used here (3-electrode system, small electrode surface area vs. solution volume) succeeded in enhancing the current densities generated by the bioanodes. It has to be concluded that current densities reported so far in the literature with

Table 1

Total COD removal yield, Coulombic efficiency (CE), and COD removal related to electricity production (e $\triangle \mathrm{COD}$ ) at different HRT values. (A) From experiment reported in Fig. 1; (B) and (C) replicates with different effluent samples. Each HRT was maintained from 3 to 7 days.

\begin{tabular}{|c|c|c|c|c|c|c|}
\hline $\begin{array}{l}\text { HRT } \\
(h)\end{array}$ & $\begin{array}{l}\text { COD } \\
\text { input } \\
(\mathrm{mg} / \mathrm{L})\end{array}$ & $\begin{array}{l}\text { COD } \\
\text { output } \\
(\mathrm{mg} / \mathrm{L})\end{array}$ & $\begin{array}{l}J \text { average } \\
\left(\mathrm{A} / \mathrm{m}^{2}\right)\end{array}$ & $\begin{array}{l}\text { COD } \\
\text { removal } \\
\text { yield (\%) }\end{array}$ & CE & $\begin{array}{l}\mathrm{e}-\Delta \mathrm{COD} \\
(\mathrm{mg} / \mathrm{L})\end{array}$ \\
\hline \multicolumn{7}{|l|}{$A$} \\
\hline 48 & 1623 & 1257 & 3.5 & 23 & 25 & 91 \\
\hline 24 & 1443 & 1145 & 4.5 & 21 & 20 & 60 \\
\hline 12 & 1389 & 1097 & 4.5 & 21 & 12 & 35 \\
\hline 6 & 1284 & 1046 & 4.5 & 19 & 8 & 19 \\
\hline \multicolumn{7}{|l|}{$B$} \\
\hline 41 & 1260 & 978 & 3.3 & 22 & 16 & 45 \\
\hline 24 & 1080 & 813 & 3.0 & 25 & 12 & 32 \\
\hline 14 & 1300 & 1009 & 3.5 & 22 & 4 & 12 \\
\hline \multicolumn{7}{|l|}{ C } \\
\hline 26 & 1300 & 1000 & 5.0 & 23 & 18 & 54 \\
\hline 18 & 1000 & 800 & 4.5 & 20 & 19 & 38 \\
\hline 8 & 1300 & 900 & 5.0 & 31 & 6 & 24 \\
\hline
\end{tabular}

MFC set-ups were significantly lower than the maximum current the bioanodes could reach, because of limitation due to the devices. The results obtained with MFC set-ups probably underestimated the current that microbial bioanodes could ensure in raw industrial effluents.

\subsubsection{COD removal and Coulombic efficiency}

During the whole duration of the experiment (1 month) the COD of the inlet effluent decreased from 1623 to $1284 \mathrm{mg} / \mathrm{L}$ because of spontaneous consumption of the organic matter it contained, in spite of rigorous storage conditions under nitrogen and at $4{ }^{\circ} \mathrm{C}$. Consequently, it was necessary to measure COD in both the inlet and the outlet flows for each measurement to obtain an accurate evaluation of the performance of the reactors. Average COD removal and CE are reported in Table 1 for each approximately 1 week period. The total COD removal yield ( $\left.Y_{\mathrm{COD}}\right)$ remained constant around $21 \% \pm 2 \%$ and did not decrease significantly when the retention time was reduced. Two replicates gave similar COD removals, which were not significantly affected by the HRT value. This experimental observation was different from those reported by similar studies but carried out with MFC setups, which stipulated that COD removal was proportional to HRT (Liu et al., 2004; Min and Logan, 2004; You et al., 2006; Di Lorenzo et al., 2010; Huang et al., 2009). A likely explanation is that a part $(20-30 \%)$ of the organic matter in the effluent used here was easy to oxidize, while the other part was recalcitrant. The easily-oxidizable part was oxidized so fast that even the lowest HRT was sufficient to achieve its complete consumption. In contrast, the recalcitrant part was not attacked even at the longest HRT. This assumption remains to be confirmed. Actually, this kind of effluent is generally $80 \%$ biodegradable in conventional aerobic conditions.

Coulombic efficiencies increased from $8 \%$ to $25 \%$ when HRT was increased from 6 to $48 \mathrm{~h}$ in reactor A. The replicates confirmed the same trend, with CEs rising from $4 \%$ to $16 \%$ when HRT increased from 14 to $41 \mathrm{~h}$. Similar relationships have already been observed in several works performed with MFCs (Liu et al., 2004; Huang and Logan, 2008a; Di Lorenzo et al., 2010). Huang et al., using a single chamber MFC fed with paper effluents, have obtained CE from 13\% to $39 \%$ with HRT increasing from 2 to 25 h. (Huang et al., 2009). The Coulombic efficiency represents the ratio of the organic matter oxidized by the bioanode with respect to the total COD abatement. CE values always less than $25 \%$ indicated that the electrochemical reactions were responsible for a minor part of the total COD removal. Low CEs, of the same order of magnitude or even less, have commonly been reported in the literature for MFCs using real raw effluents (see Section 1).

Control experiments with non-polarized electrodes were performed strictly in parallel for some of the electrochemical reactors, i.e. at exactly the same time, with the same HRTs and fed with the same effluent (see Table 2 in Supplementary data for example). In the control reactors, COD removals were generally a few percent lower than those of the corresponding polarized reactors but, in a few cases, the control gave higher COD removal. Unfortunately, only a few similar control experiments with non-polarized electrodes have been reported in the literature (Liu et al., 2004; Huang and Logan, 2008a; Huang et al., 2009). When available, they also show similar small differences between non-polarized controls and polarized reactors.

The low CE obtained under polarization and the high COD removals observed in the non-polarized control experiments confirmed that the main part of the total COD removal was not related to the electrochemical assistance. The spontaneous COD decrease was hard to control because of the complex composition of the organic matter contained in real industrial effluents. 
3.2. Modelling the effect of the hydraulic retention time (HRT) including $C O D$ variations

\subsubsection{Theory}

Raw effluents underwent spontaneous COD abatement not related to electrochemical pathways. CE expressed with respect to the total COD removal (Eq. (8)) was consequently not the most relevant parameter because it expressed the small electrochemical contribution under study with respect to a large COD removal that was hard to grasp and not related to the electrochemical process. To investigate the real impact of the electrochemical pathways on raw industrial effluent, a theoretical approach is proposed here, based only on the COD abatement related to the electrochemical reactions.

The electrochemically removed COD (e $\triangle \mathrm{COD}$ ) was defined as the amount of organic matter (COD) that was oxidized by the bioanode in a given period of time. The experimental value e $\triangle C O D_{\text {exp }}$, $\left(\mathrm{mg} / \mathrm{L}\right.$ or, identically, $\mathrm{g} / \mathrm{m}^{3}$ ) was calculated from the electrical charge extracted from the system by the bioanode:

$\mathrm{e} \Delta \mathrm{COD}_{\exp }=\frac{A}{V_{\mathrm{S}}} \frac{32}{4 F} \int_{t}^{t+\Delta t} J \mathrm{~d} t$

where $A$ is the electrode surface area $\left(\mathrm{m}^{2}\right), V_{\mathrm{S}}$ is the solution volume $\left(\mathrm{m}^{3}\right), 32$ is the molar mass of oxygen $(\mathrm{g} / \mathrm{mol}), n=4$ is the number of electrons exchanged per mol of oxygen oxidized $\left(\mathrm{mol}^{-1}\right), F=96485$ is the Faraday constant $(\mathrm{C} / \mathrm{mol}), J$ is the current density $\left(\mathrm{A} / \mathrm{m}^{2}\right)$ and $t$ is the time (s).

The theoretical value e $\Delta \mathrm{COD}_{\text {theo }}$ was obtained through the mass balance on the continuous reactor involving only the electrochemical reaction:

$\dot{V} \mathrm{e} \Delta \mathrm{COD}_{\text {theo }}=A J \frac{32}{4 F}$

Dividing each part by $\dot{V}$ and using the definition of HTR (Eq. (1)) led to the expression for the theoretical electrochemical COD removal $\left(\mathrm{e} \triangle \mathrm{COD}_{\text {theo }}\right)$ :

$\mathrm{e} \Delta \mathrm{COD}_{\text {theo }}=\frac{32}{4 F} \frac{A}{V_{\mathrm{S}}} \mathrm{HRT} \cdot \mathrm{J}$

A conventional Michaelis-Menten-type law was introduced to express the variation of the current density with COD:

$J=J_{\max } \frac{\mathrm{COD}}{K_{\mathrm{COD}}+\mathrm{COD}}$,

where $J_{\max }\left(\mathrm{A} / \mathrm{m}^{2}\right)$ is the maximum current that could be provided by the bioanode at the applied potential in optimal COD conditions, and $K_{\mathrm{COD}}$ the Michaelis-Menten equivalent constant in terms of $\operatorname{COD}\left(\mathrm{g} / \mathrm{m}^{3}\right.$ or $\left.\mathrm{mg} / \mathrm{L}\right)$. Such a relationship between substrate concentration ( $\mathrm{mM}$ ) and current density has been established for acetate (Kato Marcus et al., 2007; Hamelers et al., 2011) and has also been shown to be suitable for use with COD for complex substrates (Min and Logan, 2004). Actually, this equation has generally been referred as a Monod-type law, but we prefer to use the "MichaelisMenten" qualification because the phenomenon is controlled by the enzymatic mechanisms that control substrate oxidation rather than being related to microbial growth for which the Monod law was established.

Finally, according to the well-stirred hypothesis, the COD concentrations of the outlet flow and inside the reactor were assumed to be equal. This hypothesis was justified here by the continuous stirring ensured by nitrogen sparging. The electrode was exposed to a COD concentration equal to those of the outlet flow, which gave the expression for $J$ :

$J=J_{\max } \frac{\mathrm{COD}_{\text {output }}}{K_{\mathrm{COD}}+\mathrm{COD}_{\text {output }}}$ and led to the theoretical expression for e $\Delta \mathrm{COD}_{\text {theo: }}$ :

$\mathrm{e} \Delta \mathrm{COD}_{\text {theo }}=\frac{32}{4 F} \frac{A}{V_{\mathrm{S}}} \mathrm{HRT} \cdot J_{\max } \frac{\mathrm{COD}_{\text {output }}}{K_{\mathrm{COD}}+\mathrm{COD}_{\text {output }}}$.

This expression gives the COD removal due to the electrochemical process as a function of HRT and the COD in the outlet flow. The function e $\triangle C O D_{\text {theo }}$ is not biased by the large part of COD that is consumed by non-electrochemical routes and gives an accurate estimation of the amount of COD consumed by the electrochemical process.

Eq. (13) confirm that the efficiency of a bioanode is proportional to the "electrode surface area/solution volume" ratio, as is the case for any conventional electrochemical process. Here the volume was deliberately chosen high $(0.5 \mathrm{~L})$ with respect to the electrode surface area $\left(10 \mathrm{~cm}^{2}\right)$, giving a small $A / V_{S}$ ratio of $2 \mathrm{~m}^{2} / \mathrm{m}^{3}$. Generally, studies carried out with MFC set-ups have involved larger $A / V_{\mathrm{S}}$ ratios: $8.2 \mathrm{~m}^{2} / \mathrm{m}^{3}$ (Mathuriya and Sharma, 2009a) $10.7 \mathrm{~m}^{2} / \mathrm{m}^{3}$ (Li et al., 2007) or $18.2 \mathrm{~m}^{2} / \mathrm{m}^{3}$ (Huang et al., 2009). The choice made here succeeded in promoting high current densities as targeted (see Section 1) but it was detrimental to the electrochemical efficiency for organic removal. Eq. (13), which can be transformed to:

$\frac{e-\Delta \operatorname{COD}_{\text {theo }}}{J}=$ Constant $\frac{A}{V_{\mathrm{S}}} \mathrm{HRT}$

expresses the opposition between the two targets: promoting large electrochemical COD abatement is favoured by high values of the $A$ / $V_{\mathrm{S}}$ ratio, while targeting high current densities requires low $A / V_{\mathrm{S}}$ values.

\subsubsection{Theoretical fitting of the experimental data}

The theoretical e $\Delta \mathrm{COD}_{\text {theo }}$ equation (Eq. (13)) was fitted to the experimental values extracted from the charge $\left(e \Delta C O D_{\exp }\right)$ by adjusting the two parameters $J_{\max }$ and $K_{\mathrm{COD}}$ (Fig. 2). The values of $J_{\max }=6 \mathrm{~A} / \mathrm{m}^{2}$ led to satisfactory fitting of experiment A, except for the first point recorded at HRT $=48 \mathrm{~h} . J_{\max }=6 \mathrm{~A} / \mathrm{m}^{2}$ was perfectly realistic value with respect to the $J_{\max }$ given by the CV curves (Fig. 1). The first phase of experiment $\mathrm{A}$ at $\mathrm{HRT}=48 \mathrm{~h}$ gave lower current $\left(3.5 \mathrm{~A} / \mathrm{m}^{2}\right)$ than the subsequent phases $\left(4.5 \mathrm{~A} / \mathrm{m}^{2}\right)$ (Fig. 1). The $J_{\max }$ parameter was consequently decreased in the same proportion $\left(4.7 \mathrm{~A} / \mathrm{m}^{2}\right.$ instead of $\left.6 \mathrm{~A} / \mathrm{m}^{2}\right)$ for the point at HRT $48 \mathrm{~h}$. This adaptation led to a very satisfactory fit of the whole experiment and it also showed the consistency of the model with the experimental behaviour. For experiment $B$, the best fit was obtained with $J_{\max }$ of $3 \mathrm{~A} / \mathrm{m}^{2}$, which was also consistent with the lower current densities obtained in this experiment. Experiment $C$ was fitted with $J_{\max }=6 \mathrm{~A} / \mathrm{m}^{2}$ identically to experiment A. The $K_{\mathrm{COD}}$ constant remained unchanged, equal to $400 \mathrm{mg} / \mathrm{L}$ for all experiments.

\subsubsection{Model validation on a large range of inlet COD concentrations}

The objective of the following experiments was to explore the model robustness on a larger range of COD values obtained by diluting the inlet effluent. Two reactors (D and $E$ ) were run in parallel and fed with the same effluent (duplicates). As previously, the bioanodes were firstly formed by 5 day polarization in batch. The reactors were then switched to continuous mode with an HRT of $24 \mathrm{~h}$. The two reactors exhibited slight differences in currents but showed identical global behaviours (Fig. 3). As in the previous experiments, there was an initial unstable current phase for a few days after the reactor had been set in continuous mode. Thereafter the reactors produced quite stable currents (from day 12 to day 18 ), which slowly decreased because of the slow spontaneous decrease of the inlet COD concentration. After day 18, the HRT was decreased by periods of around 1 week and the COD inlet was concomitantly reduced from 1650 to $500 \mathrm{mg} / \mathrm{L}$ by diluting the effluent with fresh water, resulting in a progressive decrease of the current 


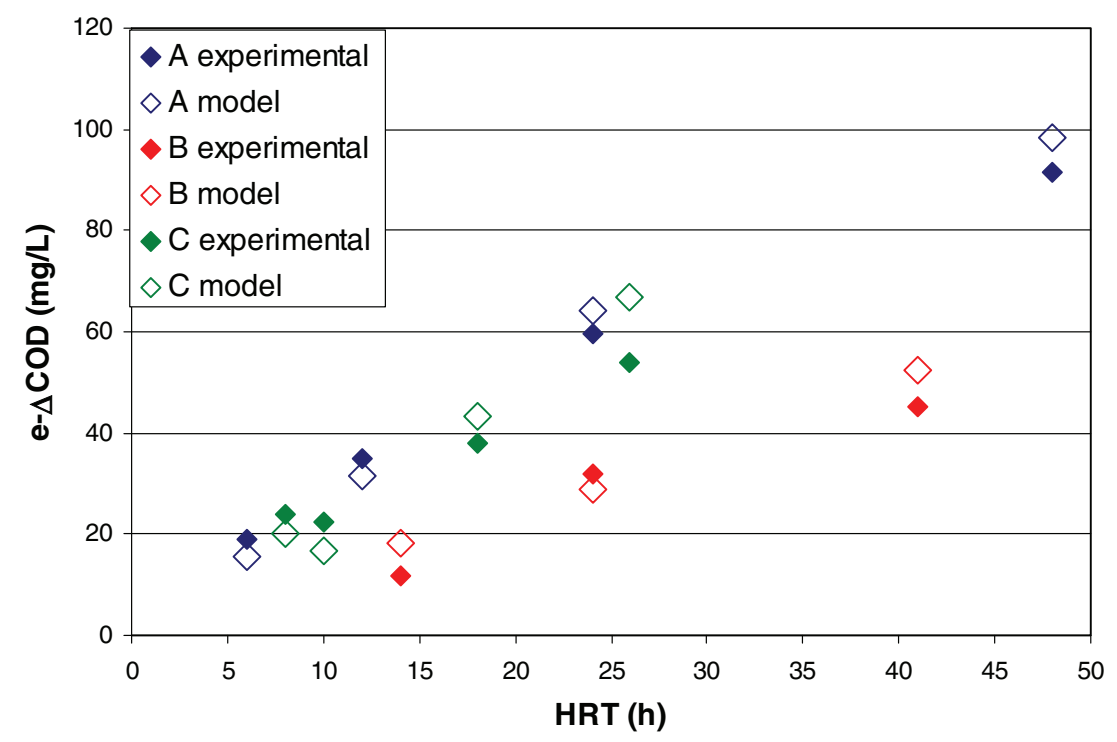

Fig. 2. Comparison of the experimental (full diamonds) and theoretical (empty diamonds) COD removals related to the electrochemical reaction for the three experiments reported in Table 2.

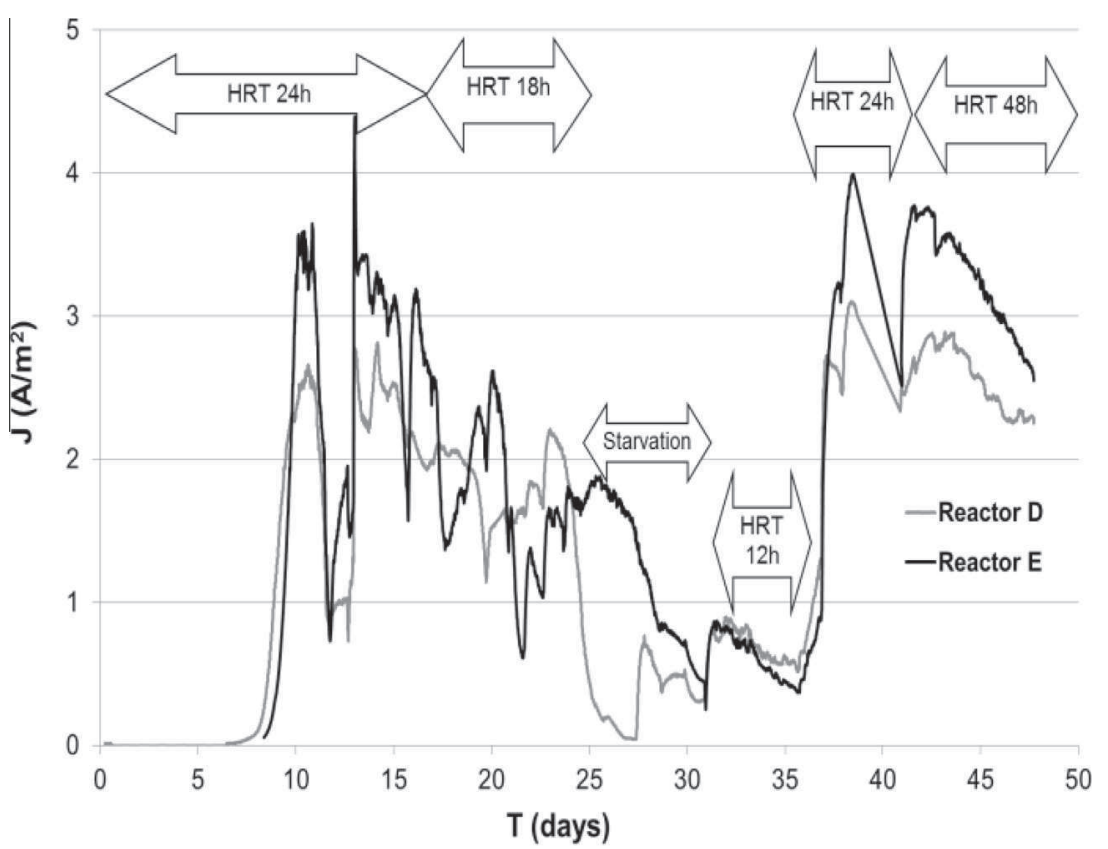

Fig. 3. Current density produced under constant polarization at $-0.3 \mathrm{~V} / \mathrm{SCE}$ during continuous operation at different HRTs with two identical reactors run in parallel (reactors $\mathrm{D}$ and $\mathrm{E}$ ). The first 5 days corresponded to bioanode formation in batch mode.

produced. When COD was finally increased to 900 and then $1500 \mathrm{mg} / \mathrm{L}$ in the last two phases (after day 35), the bioanodes recovered current values of the same order of magnitude as in the starting phase, showing a nice stability of the current for more than 6 weeks.

The theoretical values e $\triangle \mathrm{COD}_{\text {theo }}$ were fitted to the experimental data with $J_{\max }=4.75 \mathrm{~A} / \mathrm{m}^{2}$ and $K_{\mathrm{COD}}=400 \mathrm{mg} / \mathrm{L}$ for both duplicates (Fig. 4A). The model gave an accurate representation of the experiments, with errors between theory and experiment of the same order of magnitude as the experimental deviations between the duplicates. It can be concluded that Eq. (13) gave a robust and accurate description of the reactor behaviours in a large range of HRT (6-48 h) and inlet COD values $(500-1650 \mathrm{mg} / \mathrm{L})$. Among the two adjustable parameters, the $K_{\mathrm{COD}}$ value did not vary from one experiment to the other, showing that it was probably related to the nature of the effluent and to the properties of the microbial population it contained. The model finally had only one parameter to be adjusted from one experiment to the other, $J_{\max }$, the value of which varied consistently with the current recorded experimentally.

\subsection{Discussion on the coupled experimental-model approach}

All experiments were fitted with a single value of $K_{\text {COD }}$ of $400 \mathrm{mg} / \mathrm{L}$. A similar relationship used to fit the power supplied by an MFC fed by domestic effluents has led to $K_{\mathrm{COD}}$ of the same order of magnitude (461 and $719 \mathrm{mg} / \mathrm{L}$; (Min and Logan, 2004)). Bioanodes formed with acetate (Hamelers et al., 2011) gave $K_{\text {acetate }}$ of $2.2 \mathrm{mM}$ in acetate concentration, which corresponds to $180 \mathrm{mg} /$ $\mathrm{L}$ in COD. The present study confirmed the wide applicability of a 

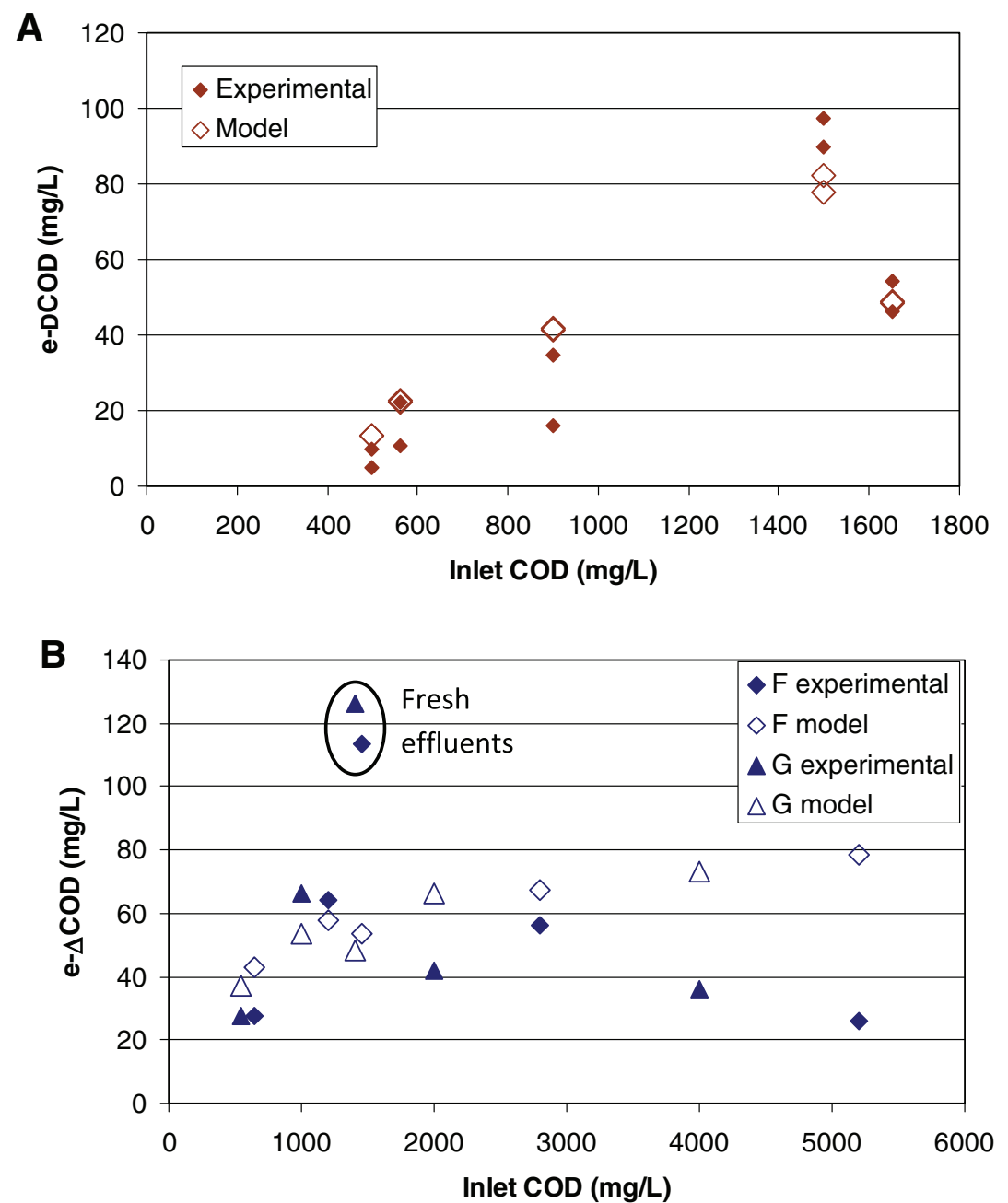

Fig. 4. Comparison of the experimental (full diamonds and triangles) and theoretical (empty diamonds or triangles) COD removals due to the electrochemical reaction as a function of the COD of the inlet flow; (A) reactors D and E with different HRT (see Table 2 in Supplementary data); (B) reactors F and G with constant HRT of 24 h, extending the COD range to high values.

Michaelis-Menten law for microbial bioanodes, whatever the substrate nature. It should be kept in mind that the COD value to be taken into account is the value to which the electrode is exposed. In the case of continuous operation under the hypothesis of a well-stirred reactor, the COD to be considered is the value of the outlet flow.

Studies that have investigated the effect of COD on MFC performance have generally observed lower CE for higher COD, in COD ranges up to around $1000 \mathrm{mg} / \mathrm{L}$ (Min et al., 2005; Huang et al., 2009; Lee et al., 2010; Wen et al., 2010; Lefebvre et al., 2013). Different hypotheses have been proposed depending on the feeding mode of the MFC. Under fed batch, various works using synthetic xylose effluent (Huang and Logan, 2008b) or industrial paper effluent (Huang and Logan, 2008a; Huang et al. 2009) have stated that the accumulation of intermediates in the reactor may be responsible for lowering CEs at high COD. Nevertheless, this possible effect is ruled out when the MFC is operated in continuous mode. Most authors attribute CE lowering with COD increase to the complexity of the organic matter present in the effluent but with no obvious explanation, except for Nam et al. (2010) who explained that the complex substrates present in the wastewater induced a high internal resistance, which limited power generation. The decrease of $\mathrm{CE}$ would consequently be due to a limitation that is not related to the bioanode itself (Nam et al., 2010). This assumption explains why CE decrease with COD was not observed here, because experiments carried out in 3-electrode set-ups are not affected by the internal resistance of the cell.

The model predicted a straightforward proportionality between e $\triangle$ COD and HRT, which was not obvious from the raw experimental data alone. For instance, such proportionality was not directly visible in Fig. 2 or when the data from Fig. 4A were plotted as a function of HRT (data not shown). Actually, the points reported in Fig. 2 corresponded to different inlet COD values ranging from 1000 to $1623 \mathrm{mg} / \mathrm{L}$ because of non-controlled drift of the effluent and the effluent variability depending on sampling time at the industrial site. Data reported in Fig. 4A show an even larger variation because of deliberate dilutions. It is not possible to compensate the COD drift of the effluent experimentally by adding acetate when the choice has been made to work with raw industrial effluent only. In this fairly cumbersome experimental framework, the model offered a powerful tool to extract sound conclusions from complex experimental data. For each reactor, the model proved to fit the experimental points satisfactorily with values of $J_{\max }$ that were consistent with the experimental observations. From the set of five reactors, fed with different effluent samples, it could thus be concluded that Eq. (13) was respected, meaning that the bioanodes oxidized amounts of organic matter that increased proportionally to HRT. This proportional increase was qualified by the concentration of COD that remained in the reactor $\left(\mathrm{COD}_{\text {output }}\right)$ affecting the current through 
a Michaelis-Menten law. From a practical point of view, Eq. (13) gave a first tool for optimizing the reactor design $\left(A, V_{S}\right)$ and gave the operating parameter (HRT) as a function of the bioanode characteristics $\left(J_{\max }, K_{\mathrm{COD}}\right)$ depending on the target: favouring COD removal or favouring electricity production.

\subsection{Using the model to investigate the effect of high inlet COD concentrations}

The initial phase of bioanode formation in batch was avoided in this section by using a bioanode that had already been used in a previous reactor. The bioanode was extracted from the initial reactor after 75 days of operation in continuous mode and transferred into a new reactor (reactor $F$ ) without any particular care (in particular transfer was made in air). The reactor was then immediately put under continuous feed with raw effluent. HRT was maintained at $24 \mathrm{~h}$ in all experiments and only the inlet COD was varied. The current density started to increase immediately and reached a maximum of $3.8 \mathrm{~A} / \mathrm{m}^{2}$ after only 1 week. The inlet COD was varied from 500 to $5200 \mathrm{mg} / \mathrm{L}$. Each concentration level was maintained for 1 or 2 weeks. The maximum current densities, between 2.6 and $3.8 \mathrm{~A} / \mathrm{m}^{2}$, were obtained with COD from 1200 to $2800 \mathrm{mg} / \mathrm{L}$ and currents were significantly reduced with the lowest and highest values of the inlet COD. The experiment replicated in identical conditions (reactor $\mathrm{G}$ ) gave similar results. The experimental and theoretical COD removals due to the electrochemical reaction (e $\triangle C O D$ ) were calculated as previously and fitting was done with $J_{\max }=4.75 \mathrm{~A} / \mathrm{m}^{2}$ and $K_{\mathrm{COD}}=400 \mathrm{mg} / \mathrm{L}$ for both reactors (Fig. $4 \mathrm{~B}$ ).

The model fitted the experimental e $\Delta$ COD obtained at low COD inlet well for both reactors but a surprisingly high electrochemical COD abatement was obtained for each reactor at the inlet CODs of 1460 and $1300 \mathrm{mg} / \mathrm{L}$. These two measurements were obtained when the effluents in the storage tank were replaced by freshly collected effluents. In the previous experiments (A-E) a fresh effluent was used at the beginning of the experiment and was first used for 1 week in batch mode to form the bioanode. In contrast, in reactors $\mathrm{F}$ and $\mathrm{G}$, the fresh effluent was not used at the beginning but only after 2 weeks of continuous operation. The possible effect of the fresh effluent was consequently not observed in the previous reactors because of the initial batch phase, while here both reactors showed a considerably higher electrochemical COD abatement with fresh effluents. Freshly collected effluents containing easily biodegradable compounds were more sensitive to the treatment by the microbial bioanodes.

Chemical analysis of the freshly collected effluent revealed that a significant part of the COD was composed of volatile fatty acids, mainly including acetic acid $(200 \mathrm{mg} / \mathrm{L})$, propionic acid $(98 \mathrm{mg} / \mathrm{L})$ and butyric acid ( $36 \mathrm{mg} / \mathrm{L})$. Trace amounts ( $<10 \mathrm{mg} / \mathrm{L}$ ) of lactic, formic, butyric, isobutyric, valeric and isovaleric acids were also found. After 1 week of storage at $4{ }^{\circ} \mathrm{C}$, acetic, propionic and butyric acids decreased to 64,29 and $35 \mathrm{mg} / \mathrm{L}$, respectively, while formic acid increased slightly from 10 to $16 \mathrm{mg} / \mathrm{L}$. The COD composition of the effluent evolved significantly during the first week although it was stored at low temperature under nitrogen. The high concentration of acetate in the freshly collected effluent was the cause of the unpredicted high electrochemical abatements observed at 1460 and $1300 \mathrm{mg} / \mathrm{L}$ COD inlet in reactors F and G.

For both reactors, the electrochemical COD abatement decreased at the highest inlet COD values, above approximately $3000 \mathrm{mg} / \mathrm{L}$. The model clearly indicated that the e $\Delta$ COD should increase slightly with increasing inlet COD, while the experimental data showed a reverse trend. This obvious discrepancy between model and experiment evidenced an inhibition effect caused by the high organic matter contents. Substrate or product inhibition at the highest substrate concentrations have been suggested (Rabaey et al., 2005; Di Lorenzo et al., 2010; Pocaznoi et al., 2012) but inhibition by the substrate is more likely in continuous mode, which avoids the accumulation of products in the reactor. With real effluents, substrate inhibition has already been observed (Liu et al., 2005) but at slightly lower threshold values than found here, above $1500 \mathrm{mg} / \mathrm{L}$ (Min et al., 2005). Du et al. (2007) have suggested that high COD brings a large amount of non-conductive components in the effluent that can form a resistive coating on the electrode surface during the earlier step of microbial adhesion. This hypothesis was not acceptable here because the high COD effluents were supplied to bioanodes formed with low COD, which had previously exhibited high performance. Substrate inhibition has also been observed with simple substrates like acetate, ethanol and glucose (Sharma and Li, 2010) above concentrations of the order of $20-35 \mathrm{mM}$ or $50 \mathrm{mM}$ (Pocaznoi et al., 2012). The threshold of $3000 \mathrm{mg} / \mathrm{L}$ COD observed here corresponded to an equivalent concentration of $35 \mathrm{mM}$ of acetate.

The coupled model and experimental data confirmed the validity of Eq. (13). The electrochemical COD removal increased proportionally to HRT, as commonly observed in MFC studies analysed through Coulombic efficiencies. In contrast, the electrochemical COD removal increased with COD, in contradiction with some previous conclusions that have been extracted from MFC experiments. Variation of the electrochemical COD removal was inhibited above around $3000 \mathrm{mg} / \mathrm{L}$, a threshold that was higher than reported so far with raw effluents in MFC experiments, but similar to values observed with simple substrates.

\section{Conclusions}

The objective of the work was to assess the performance of microbial bioanodes formed in raw pulp and paper effluents. Using 3-electrode set-ups led to maximal current densities higher than reported so far with real effluents in studies that implemented complete MFC devices.

A large part of COD removal was caused by side-reactions that did not produce electricity. It was consequently proposed to consider the "electrochemical COD removal" to make an accurate estimation of the bioanode performance. A theoretical model was developed to interpret the experimental data obtained with effluents whose composition is not stable.

\section{Acknowledgement}

This work was achieved in the framework of the "Agri-Elec (ANR-008-BioE-001)" Project, which was supported by the French National Research Agency (ANR).

\section{Appendix A. Supplementary data}

Supplementary data associated with this article can be found, in the online version, at http://dx.doi.org/10.1016/j.biortech.2013.09, 025 .

\section{References}

Cheng S. Liu, H. Logan, B.E 2006. Increased power generation in a continuous flow MFC with advective flow through the porous anode and reduced electrode spacing. Environ. Sci. Technol. 40, 2426-2432.

Di Lorenzo, M., Scott, K., Curtis, T.P., Head, I.M., 2010. Effect of increasing anode surface area on the performance of a single chamber microbial fuel cell. Chem. Eng. J. 156, 40-48.

Du, Z., Li, H., Gu, T., 2007. A state of the art review on microbial fuel cells: a promising technology for wastewater treatment and bioenergy. Biotechnol. Adv. 25, 464-482.

Hamelers, H.V.M., Ter Heijne, A., Stein, N., Rozendal, R.A., Buisman, C.J.N., 2011. Butler-Volmer-Monod model for describing bio-anode polarization curves. Bioresour. Technol. 102, 381-387. 
Huang, L., Logan, B., 2008a. Electricity generation and treatment of paper recycling wastewater using a microbial fuel cell. Appl. Microbiol. Biotechnol. 80, 349355.

Huang, L., Logan, B., 2008b. Electricity production from xylose in fed-batch and continuous-flow microbial fuel cells. Appl. Microbiol. Biotechnol. 80, 655-664.

Huang, L., Cheng, S., Rezaei, F., Logan, B., 2009. Reducing organic loads in wastewater effluents from paper recycling plants using microbial fuel cells. Environ. Technol. 30, 499-504.

Kassongo, J., Togo, C.A., 2011. Evaluation of full-strength paper mill effluent for electricity generation in mediator-less microbial fuel cells. Afr. J. Biotechnol. 10, 15564-15570.

Kato Marcus, A., Torres, C.I., Rittmann, B.E., 2007. Conduction-based modeling of the biofilm anode of a microbial fuel cell. Biotechnol. Bioeng. 98, 1171-1182.

Lee, C.-Y., Chen, J.-H., Cai, Y.-Y., 2010. Bioelectricity generation and organic removal in microbial fuel cells used for treatment of wastewater from fish-market. J. Environ. Eng. Manage. 20, 173-180.

Lefebvre, O., Tan, Z., Shen, Y., Ng, H.Y., 2013. Optimization of a microbial fuel cell for wastewater treatment using recycled scrap metals as a cost-effective cathode material. Bioresour. Technol. 127, 158-164.

Li, Z., Yao, L., Kong, L., Liu, H., 2007. Electricity generation using a baffled microbial fuel cell convenient for stacking. Bioresour. Technol. 99, 1650-1655.

Liu, H., Ramanathan, R., Logan, B., 2004. Production of electricity during wastewater treatment using a single chamber microbial fuel cell. Environ. Sci. Technol. 38, $2281-2285$.

Liu, H., Cheng, S., Logan, B., 2005. Production of electricity from acetate or butyrate using a single-chamber microbial fuel cell. Environ. Sci. Technol. 39, 658-662.

Logan, B.E., Rabaey, K., 2012. Conversion of wastes into bioelectricity and chemicals by using microbial electrochemical technologies. Science 337, 686-690.

Lu, N., Zhou, S.-G., Zhuang, L., Zhang, J.-T., Ni, J.-R., 2009. Electricity generation from starch processing wastewater using microbial fuel cell technology. Biochem. Eng. J. 43, 246-251.

Mathuriya, A.S., Sharma, V.N., 2009. Bioelectricity production from various wastewaters through microbial fuel cell technology. J. Biochem. Technol. 2 (1), 133-137.
Min, B., Logan, B.E., 2004. Continuous electricity generation from domestic wastewater and organic substrates in a flat plate microbial fuel cell. Environ. Sci. Technol. 38, 5809-5814.

Min, B., Kim, J., Oh, S., Regan, J.M., Logan, B.E., 2005. Electricity generation from swine wastewater using microbial fuel cells. Water Res. 39, 4961-4968.

Nam, J.-Y., Kim, H.-W., Lim, K.-H., Shin, H.-S., 2010. Effects of organic loading rates on the continuous electricity generation from fermented wastewater using a single-chamber microbial fuel cell. Bioresour. Technol. 101, 33-37.

Pocaznoi, D., Erable, B., Etcheverry, L., Delia, M.-L., Bergel, A., 2012. Towards an engineering-oriented strategy for building microbial anodes for microbial fuel cells. Phys. Chem. Chem. Phys. 14, 13332-13343.

Rabaey, K., Clauwaert, P., Aelterman, P., Verstraete, W., 2005. Tubular microbial fuel cells for efficient electricity generation. Environ. Sci. Technol. 39, 80778082.

Sharma, Y., Li, B., 2010. The variation of power generation with organic substrates in single-chamber microbial fuel cells (SCMFCs). Bioresour. Technol. 101, 18441850.

Stephenson, R., Mahmood, T., Elliot, A., O'Connor, B., Eskicioglu, C., Saha, M., Ericksen, B., 2012. How microsludge and anaerobic digestion or aerobic stabilization of waste activated sludge can save on sludge management costs. J. Sci. Technol. For. Prod. Processes 2, 26-31.

Wen, Q., Wu, Y., Zhao, L., Sun, Q., 2010. Production of electricity from the treatment of continuous brewery wastewater using a microbial fuel cell. Fuel 89, 13811385.

You, S.J. Zhao, Q.L. Jiang, J.Q, Zhang, J.N., 2006. Treatment of domestic wastewater with simultaneous electricity generation in microbial fuel cell under continuous operation. Chem. Biochem. Eng. 20, 407-412.

Youngho, A., Logan, B., 2010. Effectiveness of domestic wastewater treatment using microbial fuel cells at ambient and mesophilic temperatures. Bioresour. Technol. 101, 469-475.

Zhang, F., Ge, Z., Grimaud, J., Hurst, J., He, Z., 2013. Long-term performance of literscale microbial fuel cells treating primary effluent installed in a municipal wastewater treatment facility. Environ. Sci. Technol. 47, 4941-4948. 